\title{
Utilization of neutralized spent sulfuric acid pickle liquor from metal treatment in cement production
}

\author{
E. Jarosz-Krzemińska $\cdot$ E. Helios-Rybicka • \\ M. Gawlicki
}

Received: 27 January 2014/Revised: 27 August 2014/Accepted: 19 October 2014/Published online: 5 November 2014

(C) The Author(s) 2014. This article is published with open access at Springerlink.com

\begin{abstract}
The research addresses the issue of utilization of neutralized spent sulfuric acid pickling liquor, deposited in 1.62 ha lagoons, derived from steel industry, in cement production. Physical-chemical characteristics of the investigated waste revealed low levels of contaminants with the exception of sulfate anions. However, the presence of $\mathrm{CaSO}_{4} \cdot 2 \mathrm{H}_{2} \mathrm{O}$ revealed a new utilization option for the investigated waste. A key part of the research involved studying the usability of stored waste as a substitute of natural gypsum, acting as a set retarder in cement production. Cement was prepared by grinding Portland clinker with the addition of waste gypsum and then was subjected to the examinations of initial setting time, specific surface, water demand and compressive strength. The analysis of mechanical and physical properties revealed that the tested cement with the addition of waste meets standard requirements for Portland cement. Furthermore, the study of natural radioactivity of the waste did not reveal a rise in the level of radionuclides, thus confirming that the investigated waste can be used for the production of construction materials used in buildings intended for human residence. Utilization of the deposited wastes can help eliminate the environmental hazards regarding sulfuric acid pickle liquor waste and can also provide a low-cost resource of waste gypsum, which can be widely used in the production of construction materials.
\end{abstract}

E. Jarosz-Krzemińska $(\bowtie) \cdot$ E. Helios-Rybicka

Faculty of Geology, Geophysics and Environmental Protection, AGH University of Science and Technology,

Al. A. Mickiewicza 30, 30-059 Kraków, Poland

e-mail: elzbietajarosz@geol.agh.edu.pl

M. Gawlicki

Institute of Ceramics and Building Materials, Oswiecimska 21,

45-641 Opole, Poland
Keywords By-product gypsum · Cement · Portland clinker $\cdot$ Spent pickling liquor $\cdot$ Set retarder

\section{Introduction}

Despite explicit global waste management policy guidelines, disposal is still a common method applied to industrial and hazardous wastes. What is considered a cheap and simple method of managing wastes is in fact very problematic with respect to soil contamination, odor emission, groundwater pollution and public protests. Spent pickle liquor is considered hazardous waste according to both EU and EPA legislation. Steelwork plants in European Union (EU) produce $300,000 \mathrm{~m}^{3} /$ year of spent pickling solutions (SPS), and 150,000 t/year of this waste is stored (Frias et al. 2000). Pickling solution or liquor is in fact sulfuric acid $\left(\mathrm{H}_{2} \mathrm{SO}_{4}\right)$ or the mixture of nitric $\left(\mathrm{HNO}_{3}\right)$ and fluoric (HF) acid, which is commonly employed in the process of removing surface impurities, e.g., rust, scale or welding slag from metal surface during so-called pickling treatment. Due to its potential hazardous nature, the enormous quantities of spent pickle liquor are a major environmental concern for steel industry. According to many authors (Aubé and Zinck 2008; Nemerow and Dasgupta 1991; Baba et al. 2011), the most common technology used for disposal of metal sludge and spent pickling acid is neutralization with alkaline additives such as caustic soda, liquid ammonia, quicklime, limestone or slaked lime. Other methods such as solidification/stabilization (S/S) by cementations binder have also been previously reported in the literature (Mansurm et al. 2008; Weitzman 1990; Minocha et al. 2003; Wang 2009). S/S methods are wellestablished for hazardous waste pre-disposal. They are approved by United States Environmental Protection Agency for the purpose of cleaning up of certain 
contaminated sites. S/S methods are design to solidify the wastes and to immobilize the contaminants within the binder matrix. However, in terms of global waste management hierarchy, these methods are still less favorable than reusing and recycling of the waste material.

Wastes by their very definition are often mistakenly considered useless and unnecessary material. In actuality, many types of wastes when properly managed can be reprocessed to become a source of raw material for various industrial technologies, e.g., in the production of building materials. A modern approach to construction in line with sustainable development is based on the rational consumption of non-renewable resources and the reduction of any potential adverse environmental impact. The implementation of sustainable development principles is based mainly on saving natural minerals and replacing them with substitutes, usually in the form of industrial wastes. Waste utilization in the production of building materials reduces the consumption of natural resources, cost of waste storage and protects the environment from their harmful action (Manukyan and Davydova 1996). Moreover, using wastes in the production of building materials is a highly favorable solution as long as it does not lower the quality of the final product.

Industrial and municipal wastes are commonly used in building and ceramic industries. Many authors are reporting (Barbieri et al. 2000; Cheng 2004; Wang et al. 1998; Aloisi et al. 2006; Zhang et al. 2007; Dinh Hieu et al. 2012; Qian et al. 2006) that waste incineration residues such as fly and bottom ash could be used in glass ceramics. Moreover, pozzolan wastes are commonly used in building industry in the production of light binding materials, filtering powders, acid-resistant mixtures for lining and plastering chemical reactors, walls and ceilings (Manukyan and Davydova 1996). Other study indicates (Franus et al. 2011) that spent natural glauconite from pickle bath washings treatment could be used as an additive in the production of light weight aggregates. This solution avoids generating hazardous wastes since heavy metals become built into the texture of the sinter.

Cement industry utilizes large quantities of industrial wastes in order to reduce the cost of cement production and to decrease $\mathrm{CO}_{2}$ emissions. Industrial wastes can be used as a source of raw material for clinker production (fly ash from heat and power plants, ground granulated blast furnace slag from iron and steel making and waste marble powder), as active components of common cements, set retarders, grinding aids or as an alternative fuel used in cement kilns (e.g., solid recovered fuel, used tires, plastic shavings, sewage treatment plant sludge, tannery waste and paint sludge) (Gawlicki and Małolepszy 2008).
Currently, the most commonly used calcium sulfatebearing material in the production of cement are natural gypsum, anhydrite or synthetic flue gas desulphurization gypsum (FGD) (Xiao Lu and Hui Sheng 2008; Papageorgiou et al. 2005). Utilization of various types of chemical gypsum like citrogypsum (CG), borogypsum or arsenical borogypsum wastes (ABW) was also investigated as an alternative for natural gypsum in manufacturing of Portland cement clinker (Boncukcuoğlu et al. 2002; Alp et al. 2009; Hulusi Ozkul 2000). However, as indicated by Potgieter et al. (2004), using of phosphogypsum and other synthetic gypsums to replace natural gypsum in cement is limited mainly due to varying moisture content and impurities, which can interfere with the workability of the cement. Therefore, these types of byproduct gypsum are restricted as a component in the production of for instance high aluminate cements (Singh 2000; Ayhan 1996). Because of the increasing demand for raw gypsum, cement manufactures are still searching for new alternative sources of this material.

A key part of the research involved studying the usability of stored waste, derived from steel surface pickling treatment, as a source of gypsum, acting as a set retarder in Portland cement production.

\section{Materials and methods}

\section{Study area}

The central point of interest is an area of 1.62 ha located in Sławkow (Southern Poland, 50 $18^{\prime} 20.8^{\prime \prime} \mathrm{N}, 19^{\circ} 24^{\prime} 16.5^{\prime \prime} \mathrm{E}$ ), which comprises of two lagoons filled with $80,000 \mathrm{~m}^{3}$ of waste derived from pickling steel with sulfuric acid. Postprocessed solutions were neutralized with lime suspension and in sludge form deposited in lagoons (Fig. 1), which are approximately $500 \mathrm{~m}$ to the Biała Przemsza River (the Vistula River catchment) and $100 \mathrm{~m}$ from the nearest households. This industrial wasteland is unfenced, lacks any geochemical insulation and is not capped thus rendering it susceptible to spreading. In 2009, waste samples from both lagoons were collected from 57 points. A representative sample averaged from all sampling points was used in the research.

Analysis

Physicochemical, mineralogical and toxicological characteristics of waste

The examined waste deposited in lagoons is fine grained and rusty in color due to high iron content. In order to characterize the waste stream and its toxicity, the following 


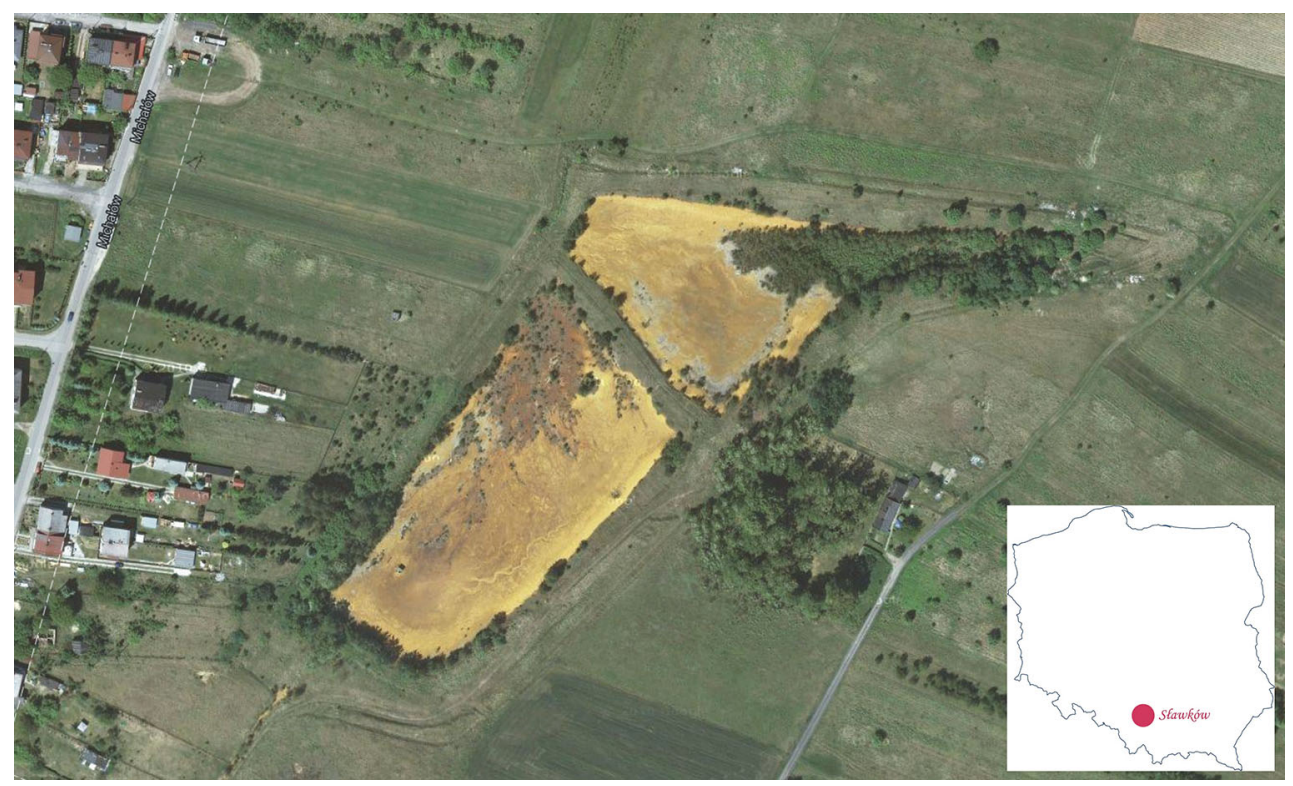

Fig. 1 Satellite image of lagoons with deposited waste

procedures were employed: in situ $\mathrm{pH}$ measurements, mineralogical composition, total chemical analysis, heavy metals content analysis, aqueous and toxicity characteristic leaching procedure (TCLP) leaching tests and measurements of waste radioactivity. Total chemical analysis of waste was performed according to EN 196-2:2006 method. To determine heavy metals concentration in waste, samples were dried in $105{ }^{\circ} \mathrm{C}$, digested with $65 \% \mathrm{HNO}_{3}$ in the START D microwave (Milestone Srl, Italy) according to EPA SW 3051A protocol and then were analyzed using dual atomizer atomic absorption spectrometer Unicam ICE 3500 (Thermo Scientific, China).

In order to characterize the mobility of contaminants and toxicity of the waste, two methods were employed. The first was an aqueous leaching test performed according to EN 12457:2006 method, the second was a TCLP performed according to US EPA 1311 method. Heavy metals in waste leachates from both aqueous and TCLP leaching tests were determined with Inductively Coupled Plasma Mass Spectrometry using Elan 6100 ICP/MS apparatus (Perkin Elmer, USA).

Mineralogical composition of the waste was determined based on powder X-ray diffraction and SEM-EDS analysis. $\mathrm{X}$-ray diffraction was performed for an air-dry powder sample using PW 3020 diffractometer (Philips, Netherlands) with the following parameters: $\mathrm{Cu} \mathrm{k} \alpha, 35 \mathrm{kV}$, $30 \mathrm{~mA}$; step by step $0.05^{\circ} 2 \theta, 1 \mathrm{~s} / \mathrm{step}$. The $\mathrm{d}$ values obtained from the X-ray pattern were used for an identification of mineral phases of the studied sample, according to the ICDD (International Centre for Diffraction Data, 2005) catalog and the computer program XRAYAN (version 4.0.5). In order to eliminate an influence of the apparatus factors on the intensity of the X-ray escape peaks, the $I_{0}$ (primary X-ray beam intensity) regulation relative to standard quartz sample was made before sample measurement.

The scanning electron microscopy analysis was performed on bulk sample using Quanta 200 FEG SEM (FEI Company, USA) equipped with a chemical composition analysis system based on energy dispersion spectroscopy EDS-EDAX. Moreover, study of natural radioactivity was performed via semiconductor gamma-ray spectroscopy.

\section{Experiment}

\section{Preparation of cement: testing mechanical and physical properties}

Production of cement requires grinding the main ingredients (such as Portland clinker, granulated blast furnace slag, fly ash, burnt shale, limestone) and secondary components with the addition of calcium sulfate-bearing material acting as set retarder. It is introduced to the cement mixture as a set retarder in small quantity (from 3.5 to $5.5 \mathrm{wt} \%$ ) to temporarily stop the hydration of tricalcium aluminate $\mathrm{C}_{3} \mathrm{~A}$, $3 \mathrm{CaO} \cdot \mathrm{Al}_{2} \mathrm{O}_{3}$, by forming ettringite (hexacalcium aluminate trisulfate hydrate, $3 \mathrm{CaO} \cdot \mathrm{Al}_{2} \mathrm{O}_{3} \cdot 3 \mathrm{CaSO}_{4} \cdot 32 \mathrm{H}_{2} \mathrm{O}$ ) coatings on $\mathrm{C}_{3} \mathrm{~A}$ grains. Without gypsum, ground clinker exhibits flash settling in a few minutes. The addition of gypsum into the cement mixture results in an appropriate initial set time of the cement and contributes to its final strength.

Waste under investigation was introduced to the cement mixture as a set retarder to ensure the proper initial setting time. Waste gypsum was a substitute of a natural gypsum. 
Cement sample ca $10 \mathrm{~kg}$ was prepared by grinding $95 \mathrm{wt} \%$ of Portland clinker with $5 \mathrm{wt} \%$ of waste in a closed-circuit mill. A $500 \mathrm{~g}$ of cement sample was mixed with $125 \mathrm{~g}$ of water in order to receive cement paste of standard consistency. European Standard EN 196-3+A1 was then employed to evaluate the setting time. In order to perform the compressive strength test in line with European Standard EN 196-1, cement mortar with the addition of waste, sand and water (ratio of cement to standard sand $1: 3$ by weight; water/cement ratio 0.50 ) were prepared. The mortar was compacted in a mold using a vibration machine. The mold consisted of three horizontal compartments having a $40 \mathrm{~mm} \times 40 \mathrm{~mm}$ cross section and a $160 \mathrm{~mm}$ length. This approach allowed for the three prismatic specimens to be prepared simultaneously. The filled molds were stored for $24 \mathrm{~h}$ in humidity above $90 \%$ and at temperature of $20^{\circ} \mathrm{C} \pm 1.0$. After $24 \mathrm{~h}$, the samples were removed from their respective molds, immediately submerged in clean water at a temperature of $20{ }^{\circ} \mathrm{C}$ and then stored there until testing. After the required elapsed time ( 2 and 28 days), the specimens were taken from wet storage, broken into two halves and each part was tested for compressive strength.

\section{Compressive strength test}

The compressive strength test was performed on six prism halves $(40 \times 40 \times 160 \mathrm{~mm})$, using Digimax Semi-Automatic Compression flexural cement tester model 65-L18B04 (Controls S.r.1, Italy).

Prism halves were placed between two auxiliary platens of hard steel and subjected to an increasing load, at a rate of $2,400 \pm 200 \mathrm{~N} / \mathrm{s}$, until fracture.

Compressive strength was calculated according to the equation:

$R_{\mathrm{c}}=F_{\mathrm{c}} / 1,600$

where $R_{\mathrm{c}}$-compressive strength (MPa), $F_{\mathrm{c}}$-maximum load at fracture $(\mathrm{N}), 1,600$ - the area of the platens $(40 \mathrm{~mm} \times 40 \mathrm{~mm})\left(\mathrm{mm}^{2}\right)$. The results were calculated as the arithmetic mean of six compressive strength determinations. Individual results for each of these six measurements did not differ by more than $5 \%$.

\section{Initial setting time and water demand}

A Vicat apparatus Toni-Technik (ACMEL, France) with needle was used to penetrate a neat cement paste of a standard consistency and to determine its initial setting time. Time elapsed starting from the beginning of the experiment (mixing cement with water) to the time at which the distance of the needle from the base plate equals $6 \pm 3 \mathrm{~mm}$ was considered to be the initial set.

\section{Fineness of cement}

In order to determine the fineness of cement, the Blaine air permeability apparatus TMM020 (Testmak, Turkey) was used.

Fineness of the cement was determined in terms of specific surface area in $\mathrm{cm}^{2} / \mathrm{g}$, and it was calculated according to Carman equation:

$S=\frac{K \cdot e^{\frac{3}{2}} \cdot T^{\frac{1}{2}}}{\rho \cdot n^{\frac{1}{2}} \cdot(1-e)}$

where $S$-specific surface $\left(\mathrm{cm}^{2} / \mathrm{g}\right), K$-constant, $T$ - time for the air to pass through the sample bed (s), $\rho$-powder density $\left(\mathrm{g} / \mathrm{cm}^{3}\right), \eta$-viscosity of air, $e$-fractional void space $=1-\mathrm{W} / \rho V_{\mathrm{c}}, W$-weight of powder sample $(\mathrm{g})$, $V_{\mathrm{c}}$-volume of cylinder to which bed is confined $\left(\mathrm{cm}^{3}\right)$.

\section{Results and discussion}

Physicochemical analysis of waste used in the production of cement revealed that material is homogeneous in terms

Table 1 Physicochemical characteristics of waste

\begin{tabular}{ll}
\hline Main components & \\
\hline $\mathrm{SO}_{3}$ & $(\mathrm{wt} \%)$ \\
$\mathrm{CaO}$ & 34.3 \\
$\mathrm{Fe}_{2} \mathrm{O}_{3}$ & 23.0 \\
$\mathrm{SiO}_{2}$ & 20.3 \\
$\mathrm{MgO}^{2}$ & 0.60 \\
$\mathrm{Al}_{2} \mathrm{O}_{3}$ & 0.30 \\
$\mathrm{FeO}$ & 0.20 \\
$\mathrm{Trace}$ metals $^{\mathrm{b}}$ & 0.15 \\
\hline $\mathrm{As}$ & $(\mathrm{mg} / \mathrm{kg})$ \\
$\mathrm{Cd}$ & 2.5 \\
$\mathrm{Co}$ & 0.3 \\
$\mathrm{Cr}$ & 2.3 \\
$\mathrm{Cu}$ & 115 \\
$\mathrm{Mn}$ & 17 \\
$\mathrm{~Pb}$ & 109 \\
$\mathrm{Tl}$ & 77 \\
$\mathrm{Zn}$ & 0.1 \\
\hline $\mathrm{Ra}$ & 145 \\
\hline
\end{tabular}

\begin{tabular}{lc}
\hline Radionuclides $^{\mathrm{c}}$ & Activity concentration $(\mathrm{Bq} / \mathrm{kg})$ \\
\hline${ }^{40} \mathrm{~K}$ & $8.00 \pm 0.80$ \\
${ }^{226} \mathrm{Ra}$ & $7.3 \pm 0.70$ \\
${ }^{228} \mathrm{Th}$ & $0.90 \pm 0.10$ \\
\hline
\end{tabular}

\footnotetext{
a According to PN-EN 196-2:2006

${ }^{b}$ Conc. $\mathrm{HNO}_{3}$ digestion followed by AAS

c Via semiconductor gamma-ray spectroscopy
} 
of both $\mathrm{pH}$ and heavy metals content. Waste samples $\mathrm{pH}$ within both lagoons ranged from 2.5 to 4.1. An averaged sample $\mathrm{pH}$ used in the experiment was equal 3.29. Chemical analysis results depicted in Table 1 show that $\mathrm{SO}_{3}(34 \%), \mathrm{CaO}(23 \%)$ and $\mathrm{Fe}_{2} \mathrm{O}_{3}(20 \%)$ are the main chemical components of the waste. The secondary components $\mathrm{MgO}, \mathrm{Al}_{2} \mathrm{O}_{3}$ and $\mathrm{FeO}$ did not exceed $1 \%$ of mass each. Furthermore, the investigated waste is characterized as having low heavy metal concentrations. The results for both leaching tests presented in Table 2 did not reveal an increased release of heavy metals into the environment, except for sulfate anions, which were highly mobile $\left(1419 \mathrm{mg} / \mathrm{dm}^{3}\right)$.

Results of waste phase composition revealed calcium sulfate dihydrate $\left(\mathrm{CaSO}_{4} \cdot 2 \mathrm{H}_{2} \mathrm{O}\right.$ gypsum) and iron oxide hydroxide $\left(\alpha-\mathrm{Fe}^{3+} \mathrm{O}(\mathrm{OH})\right.$ goethite $)$ to be the only components (Fig. 2). SEM-EDS results confirmed X-ray diffraction findings; among the dominating gypsum forms (Fig. 3, point 1), the fine grains and aggregates of goethite (Fig. 3, point 2) are visible.

Preliminary examination of waste material deposited in both lagoons revealed that low $\mathrm{pH}$ and high sulfate anion content of the investigated wastes were found to be the most important factor potentially harmful to water-soil system (Jarosz-Krzeminska et al. 2008); however, the presence of gypsum revealed a new utilization option for the waste under investigation. Low levels of radionuclides K-40, Ra-226 or Th-228 (Table 1) measured in the deposited waste conclude that the waste under investigation can be utilized for the production of construction materials used in buildings intended for human residence.

In order to estimate the accuracy and bias of the analytical methods, both blank control samples and international certified reference materials (LKSD-4 and SL-1) were prepared and analyzed randomly with the samples. Analysis of the reference materials of known concentrations was verifying and confirming the quality of the obtained results. Analytical bias was statistically insignificant $(p=0.05)$. Moreover, the precision of AAS and ICPMS systems was verified by performing system suitability test as described in analysis section and by six injections of solution. System precision was satisfactory.

The mechanical and physical properties of the cement presented in Table 3 show initial setting time for the cement paste after $170 \mathrm{~min}$, specific surface area to be $3,100 \mathrm{~cm}^{2} / \mathrm{g}$ and water demand to be equal $0.282 \mathrm{dm}^{3} / \mathrm{kg}$. Moreover, investigated samples of cement mortar reached compressive strength of $17.16 \mathrm{MPa}$ after 2 days and

Table 2 Aqueous and TCLP leaching results of waste

$\mathrm{pH}$ and concentration of As, heavy metals and anions $\left(\mathrm{mg} / \mathrm{dm}^{3}\right)$

\begin{tabular}{lllllllllllllll}
\hline Leaching methods & $\mathrm{pH}$ & $\mathrm{As}$ & $\mathrm{Cd}$ & $\mathrm{Cr}$ & $\mathrm{Cu}$ & $\mathrm{Fe}$ & $\mathrm{Ni}$ & $\mathrm{Mn}$ & $\mathrm{Pb}$ & $\mathrm{Tl}$ & $\mathrm{Zn}^{-}$ & $\mathrm{F}^{-}$ & $\mathrm{Cl}^{-}$ & $\mathrm{SO}_{4}^{-2}$ \\
\hline Aqueous leaching extract & 3.29 & 0.001 & 0.0004 & 0.01 & 0.002 & 0.08 & 0.01 & 0.18 & 0.005 & 0.0002 & 0.19 & 1.9 & 4.5 & 1,419 \\
TCLP leaching extract & 4.7 & 0.001 & 0.0002 & 0.002 & 0.01 & 0.11 & 0.01 & 0.08 & 0.001 & 0.0001 & 0.05 & n.m. & n.m. & n.m \\
Limit values $^{\mathrm{a}}$ & $6.9-9$ & 0.1 & 0.5 & 0.5 & 0.5 & 10 & 0.5 & - & 0.5 & - & 2 & 25 & 1,000 & 500 \\
\hline
\end{tabular}

a Maximum permissible values for substances introduced to the environment according to REM (2009)

n.m. not measured

Fig. 2 X-ray diffraction pattern of the waste sample used in the experiment. The diagnostic reflexes of the crystalline phases were described; $G y$ gypsum, Go goethite

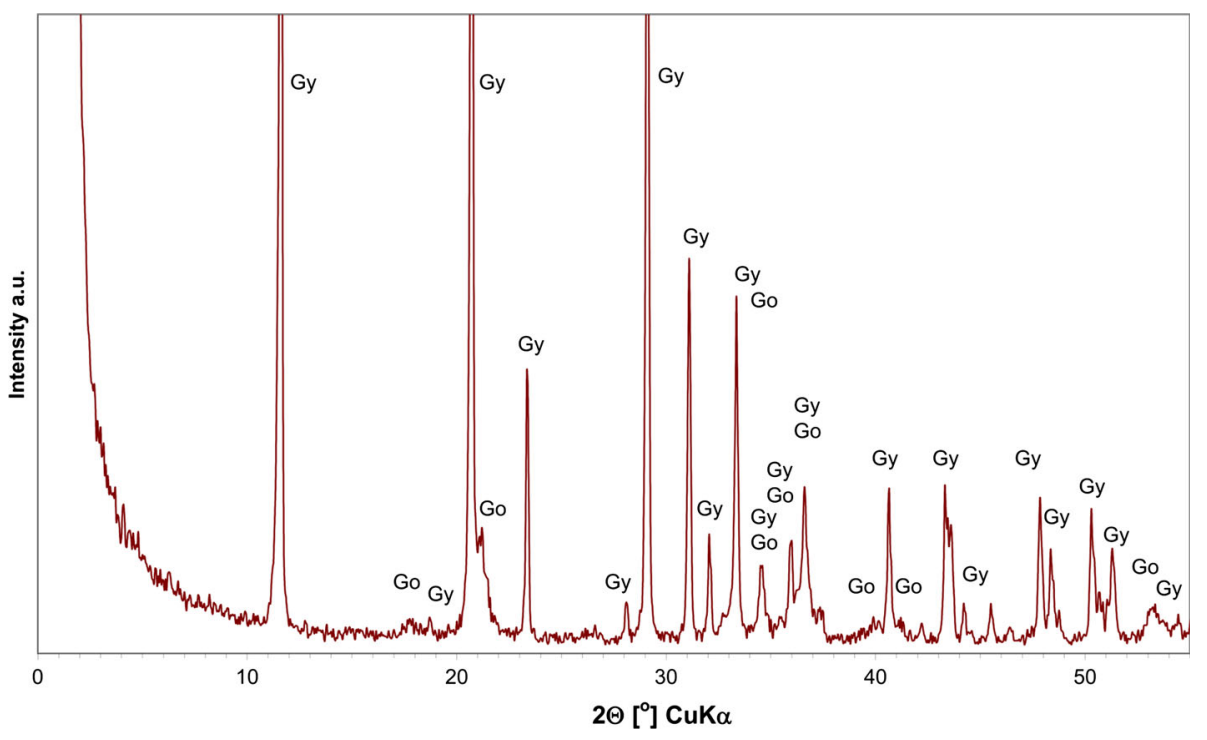




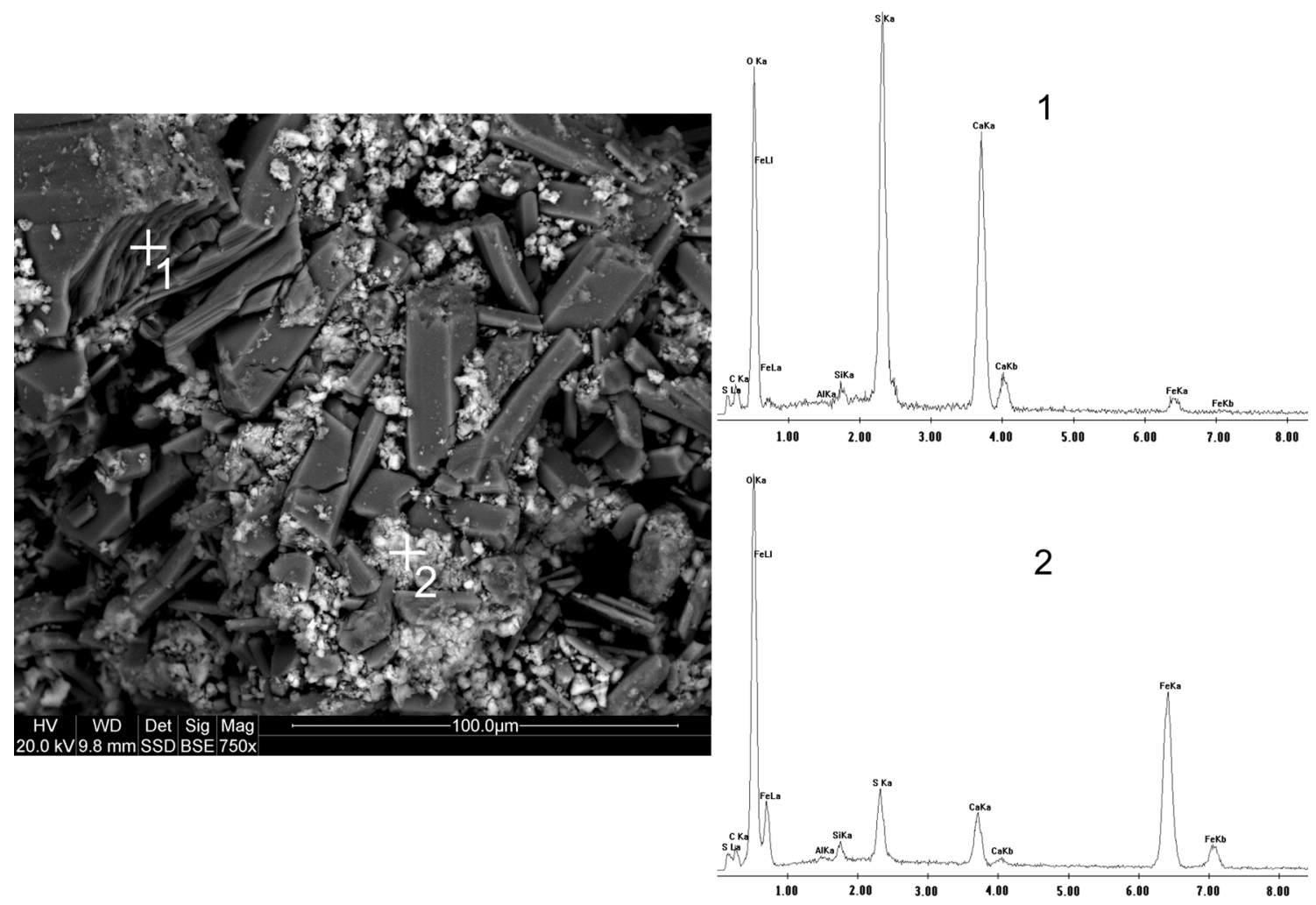

Fig. 3 Scanning electron micrographs and X-ray energy dispersive spectrums of waste. 1 gypsum, 2 goethite

Table 3 Mechanical and physical properties of cement

\begin{tabular}{lll}
\hline Compressive strength of cement mortar & & \\
After 2 days & $(\mathrm{MPa})$ & 17.16 \\
After 28 days & $(\mathrm{MPa})$ & 48.75 \\
Properties of cement & & \\
Initial setting time & $(\mathrm{min})$ & 170 \\
Water demand & $\left(\mathrm{dm}^{3} / \mathrm{kg}\right)$ & 0.282 \\
Specific surface area & $\left(\mathrm{cm}^{2} / \mathrm{g}\right)$ & 3,100
\end{tabular}

${ }^{a}$ Portland clinker, waste gypsum, sand and water examinations according to EN 196-1. "Method of testing cement-Part 1: determination of strength"

b Portland clinker ground with $5 \%$ waste gypsum, examinations according to EN 196-3 + A1. "Methods of testing cement-Part 3: determination of setting time and soundness" and EN 196-6. "Methods of testing cement-Part 6: determination of fineness"

48.75 MPa after 28 days (Table 3). The analyses of mechanical and physical properties show that the tested cement meets the standard requirements for Portland cement type CEM I $42.5 \mathrm{~N}$ (according to EN 197-1).

Results of the experiment are especially important since they introduce a new utilization method for spent acid pickling waste. Waste gypsum presented in the study is a result of neutralization of spent sulfuric acid from pickling steel with a lime suspension. There are of course other more efficient additives applied in the process of neutralization of spent pickling liquors such as sodium hydroxide $(\mathrm{NaOH})$ or potassium hydroxide $(\mathrm{KOH})$, but these are also more expensive and do not yield gypsum as a by-product. Waste gypsum used in the study has low level of contaminants and is fine grained, which according to ChengGeng et al. (2013), Payá et al. (1995) is of high importance, since the addition of smaller particle powder to the cement could strengthen the filler effect and the pozzolanic reactions and therefore it could significantly improve some properties of cement, i.e., the compressive strength. Gypsum itself besides acting as set retarder in cement has also many other industrial applications, e.g., in plasterboard production, wallboard, drywall, slip casting mold, soil conditioner in agriculture and soil improver. Therefore, waste gypsum introduced in the study can also have other end use application.

The utilization method introduced in this research is the final solution for waste deposited in lagoons. This particular industrial wasteland has been abandoned since the late 1990s and is a cause of problems for the local residents and for its manufacturer who is obliged by law to deal with it accordingly. This utilization proposal fits well under the umbrella of environmental protection by reversing the devastation of the environment and simultaneously saving 
natural resources. Furthermore, utilization of pickling waste in this manner reduces the enormous costs associated with on-site reclamation. By choosing waste material over natural gypsum, there are benefits in terms of savings for the cement manufacturer as well. The solution proposed in the research can be applied to cases involving spent sulfuric acid pickling liquor or in similar acid wastes generated by other sources.

Technology introduced in the study is more favorable solution than S/S method since it does not treat waste as a problem but rather as a quality source of secondary raw material (waste gypsum). The use of waste gypsum to replace natural gypsum as set retarder in Portland cement production is more preferable solution than its disposal according to waste hierarchy approach. Recycle or reuse waste gypsum is especially important to protect the health and environment. Waste gypsum itself is not dangerous but when mixed with organic waste and exposed to rain in an anaerobic environment hydrogen sulfide gas can evolve (Chandera et al. 2009). It is therefore especially important to reuse waste gypsum to protect the environment and human health.

\section{Conclusion}

The research results, which have been patented in 2013 (Helios-Rybicka et al. 2013 patent nr PL 216497 B1), confirm the suitability of the examined waste from the neutralization of sulfuric acid metal pickling liquor as a set retarder in cement production. Waste gypsum under investigation can successfully be used as a replacement for natural gypsum in cement production without compromising the quality and the performance of the final product. Quality analysis revealed that the cement with the addition of waste gypsum meets the requirements for Portland clinker cement CEM I $42.5 \mathrm{~N}$.

Waste under investigation is a fine-grained material, with a low level of contaminants and no heightened level of natural radionuclides. It can therefore be utilized in the production of materials used for the construction of buildings intended for human residence. The solution proposed in the study can be applied to solve similar environmental problems associated with spent sulfuric acid pickling liquor or other acidic industrial wastes of similar characteristics.

Acknowledgments The work was supported by the AGH University of Science and Technology in Krakow as research Project No. 11.11.140.190.

Open Access This article is distributed under the terms of the Creative Commons Attribution License which permits any use, distribution, and reproduction in any medium, provided the original author(s) and the source are credited.

\section{References}

Aloisi M, Karamanov A, Taglieri G, Ferrante F, Pelino M (2006) Sintered glass ceramic composites from vitrified municipal solid waste bottom ashes. J Hazard Mater B137:138-143

Alp I, Deveci H, Süngün YH, Yazici EY, Savaş M, Demirci S (2009) Leachable characteristics of arsenical borogypsum wastes and their potential use in cement production. Environ Sci Technol 43(18):6939-6943

Aubé BC, Zinck JM (2008) Optimization of lime treatment processes. Miner. Process. 93:98-105

Ayhan D (1996) Optimizing the physical and technological properties of cement additives in concrete mixtures. Cem Concr Res 26(11):1737-1744

Baba AA, Adekola FA, Awobode OS, Adekunle BR, Pradhan S, Biswal A (2011) Analysis of heavy metals from spent pickling liquor of sulfuric acid. Int J Chem 21(4):231-240

Barbieri L, Bonamartini AC, Lancellotti I (2000) Alkaline and alkaline-earth silicate glasses and glass-ceramic from municipal and industrial wastes. J Eur Ceram Soc 20:2477-2483

Boncukcuoğlu R, Tilmaz MT, Kocakerim MM, Tosunoğlu V (2002) Utilization of borogypsum as set retarder in Portland cement production. Cem Concr Res 32:471-475

Chandera Ch, Azizli AM, Ahmad ZA, Sakai E (2009) Use of waste gypsum to replace natural gypsum as set retarder in Portland cement. Waste Manag 29:1675-1679

Cheng TW (2004) Effect of additional materials on the properties of glass-ceramic produced from incinerator fly ashes. Chemosphere 56:127-131

Cheng-Geng Ch, Chang-Jung S, Sue-Huai G, Ching-Wei W, Yu-Lun Ch (2013) The effects of the mechanical-chemical stabilization process for municipal solid waste incinerator fly ash on the chemical reactions in cement paste. Waste Manag 33:858-865

Dinh Hieu V, Kuen-Sheng W, Jung-Hsing C, Bui Xuan N, Bui Hoang B (2012) Glass-ceramic from mixtures of bottom ash and fly ash. Waste Manag 32:2306-2314

Franus W, Franus M, Latosinska J, Wójcik R (2011) The use of spent glauconite in light weight aggregate production. Bol Soc Esp Ceram Vidrio 50(4):193-200

Frias C, Negro C, Formoso A, De Jong A, Pars M, Kemppanien J, Mancia F (2000) Novel process to recover by-products from the pickling baths of stainless steel. Project Funded by the European Community under the Industrial \& Material Technologies Programme (Brite-Euram III), Project BE-3501, Contract BRPR-CT97-0407

Gawlicki M, Małolepszy J (2008) Wykorzystanie odpadów przemysłowych w produkcji materiałów budowlanych. Problemy naukowo-badawcze budownictwa, Vol IV, Zrównoważony rozwój w budownictwie, Chapter 5. Recykling i zagospodarowanie odpadów w budownictwie, Wydawnictwo Politechniki Białostockiej: $389-410$

Helios-Rybicka E, Jarosz-Krzemińska E, Gawlicki M (2013) Patent PL 216497 B1 use of neutralized spent pickling waste, in the form of sludge, generated by metal surface pickling

Hulusi Ozkul M (2000) Utilization of citro-and desulphogypsum as set retarders in Portland cement. Cem Concr Res 30:1755-1758

Jarosz-Krzeminska E, Kunniakowska M, Helios-Rybicka E, Latowski D (2008) Contaminants and their mobility in post processed acidic wastes and bioaccumulation of $\mathrm{Zn}, \mathrm{Cu}$ in some plant species based on waste site in South Poland. Pol J Environ Stud 17(3A):249-253

Mansurm MB, Rocha SDF, Magalhaes FS, Benedetto JS (2008) Selective extraction of zinc(II) over iron(II) from spent hydrochloric acid pickling effluents by liquid-liquid extraction. J Hazard Mater 150:669-678 
Manukyan RV, Davydova NS (1996) Use of waste in the ceramics industry. Glass Ceram 53:247-248

Minocha AK, Jain N, Verma CL (2003) Effect of inorganic materials on the solidification of heavy metals sludge. Cem Concr Res 33:1695-1701

Nemerow NL, Dasgupta A (1991) Industrial and Hazardous Waste Treatment, 2nd edition, Van Nostrand Reinhold, ISBN: 0-44231934-7

Papageorgiou A, Tzouvalas G, Tsimas S (2005) Use of inorganic setting retarders in cement industry. Cem. Concr. Comp. 27:183-189

Payá J, Monzó J, Peris-Mora E, Borrachero MV, Tercero R, Pinillos C (1995) Early-strength development of Portland cement mortars containing air classified fly ashes. Cem Concr Res 25(2):449-456

Potgieter JH, Potgieter SS, McCrindle RI (2004) A comparison of the performance of various synthetic gypsums in plant trials during the manufacturing of OPC clinker. Cem Concr Res 34:2245-2250

Qian G, Song Y, Zhang C, Xia Y, Zhang H, Chui P (2006) Diopsidebased glass ceramics from MSW fly ash and bottom ash. Waste Manag 26:1462-1467
Singh M (2000) Influence of blended sum on the properties of Portland cement and Portland slag cement. Cem Concr Res 30:1185-1188

Wang LK (2009) Waste treatment in the metal manufacturing, forming, coating and finishing industries. Waste Treatment Bulletin, New York

Wang KS, Chiang KY, Perng JK, Sun CJ (1998) The characteristics study on sintering of municipal solid waste incinerator ashes. J Hazard Mater 59:201-210

Weitzman L (1990) Factors for selecting appropriate solidification/ stabilization methods. J Hazard Mater 24:157-168

Xiao Lu G, Hui Sheng S (2008) Thermal treatment and utilization of flue gas desulphurization gypsum as an admixture in cement and concrete. Construct Build Mater 22:1471-1476

Zhang J, Dong W, Li J, Qiao L, Zheng J, Sheng J (2007) Utilization of coal fly ash in the glass-ceramic production. J Hazard Mater 149:523-526 